\title{
Management of the appropriate agricultural biotechnology for small producers: Bolivia case study
}

\author{
Teresa Avila* \\ Pairumani's Phytoecogenetics Research Center \\ P.O. Box 128 \\ Cochabamba, Bolivia \\ Tel: 59144260083 \\ Fax: 59144263329 \\ E-mail: tavila@redbio.org \\ Juan Izquierdo \\ Senior Plant Production Officer \\ REDBIO/FAO Network Technical Secretary \\ FAO Regional Office for Latin America and the Caribbean \\ P.O. Box 10095, Santiago, Chile \\ Tel: 5623372100 \\ E-mail: juan.izquierdo@fao.org \\ http://www.redbio.org
}

Keywords: Andean crops, appropriate biotechnology, biotechnology administration, Bolivia, genetic resources, policy, REDBIO/FAO, regulations, technical cooperation network on plant biotechnology.

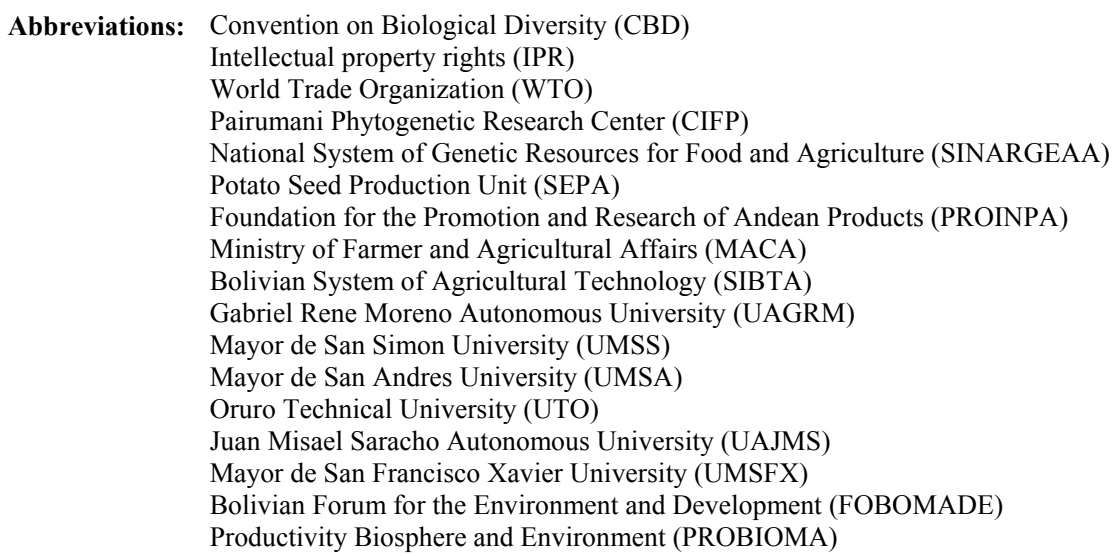

The Bolivia study is part of an ongoing multiple case study organized by the FAO's Regional Office for Latin America and the Caribbean as part of the activities of the Technical Cooperation Network on Agricultural Biotechnology (REDBIO/FAO). The basic information was obtained through a survey and/or direct interview to a significant number of experts from Bolivian institutions involving management, regulation, research, innovation, application and education of agricultural biotechnology. At national level, the most relevant applied agri-biotechnologies are presently in vitro plant culture, genomics, molecular genetics, assisted reproduction techniques in animals, and techniques supporting plant and animal disease diagnosis. They have been developed and appropriated to support the agricultural sector including genetically modified crops.
Over the past ten years, the public research and academic institutions have allocated resources to implement laboratories and others have widened and updated their facilities. Nonetheless, a different situation is observed in the private sector where some laboratories have been forced to close down and to reduce production due to the economic crisis of the country. In view of the country's specific needs and opportunities regarding conservation and utilization of genetic resources, biotechnology can constitute a valuable tool for the sustainable development of the country.

The great challenge of science nowadays, particularly for agriculture and its role in food security, is to have an impact on the sectors with fewer resources. One of the ways to

*Corresponding author 
ensure successful research planning is to prove an overview of the technological demand in the different steps of the production chains. In order for biotechnology to contribute to development, multiple aspects should be taken into account; including its rational harmonious use with environment and natural resources. It should be oriented in a responsible and viable manner towards the real needs of the country, emphasized within an appropriate biotechnological concept (Wendt and Izquierdo, 2003).

The most used biotechnological techniques which support the agricultural sector at a global level have been; in vitro plant culture, the use of molecular markers, and more recently, genetic engineering. These techniques have proven to be powerful tools to support crop genetic improvement, obtain and rapidly multiply new varieties, diagnose diseases and characterize genetic resources. In 2005, the REDBIO/FAO network in Latin America involved more than 750 laboratories dedicated mainly to in vitro culture in practically all countries for dozens of food crops, fruits, vegetables and forest species. Likewise, molecular techniques are being implemented in most of the countries of the region. Nevertheless, recombinant DNA technology is limited to technologically more advanced countries like Argentina, Brazil, Mexico and Cuba (Wendt and Izquierdo, 2003).

The biotechnological industry's best sold products in Latin America are the transgenic seeds that have been commercialized since 1996 in Argentina and most recently in various countries of Latin America (ISAAA, 2004). The second most commercialized products are the plantlets and selected cultured seeds and virus-free crops obtained by tissue culture techniques and in some cases molecular markers (CamBioTec, 2003).

The biotechnology management, at a macro-level, falls within a number of international agreements that are transformed into laws and domestic policies.

Biotechnology use was first discussed and taken to a worldwide level at the United Nations Conference on Environment and Development held in Rio de Janeiro in 1992, it was included in the $21^{\text {st }}$ Agenda and in the Convention on Biological Diversity (CBD). The Cartagena Protocol on Biosecurity, in the frame of the CBD, was adopted on September 11, 2002. To date (June 25, 2005) it has been ratified by 123 countries.

Intellectual property rights (IPR) are acquiring more importance in biotechnology management. Member countries of the World Trade Organization (WTO) consider the agreement on IPR related to commerce as the basis for their domestic legislation on this issue. The CBD has played an important role in the acknowledgement of ownership rights related to genetic resources, since it was legally recognized that the "States have sovereign rights over their own biological resources". The countries of the region consider the $391^{\text {st }}$ Decision of the Andean
Community on the Common Access to the Genetic Resources, approved in July 1996, as the legal basis for matters on this issue.

Bolivia is a remarkably rich country in biodiversity, but nevertheless, it is a country with high levels of poverty and food insecurity. It has an agricultural sector facing the impact of low export crop productivity due to multiple constraints; ranging from extensive agricultural land degradation, irrigation water distribution shortages, lack of technology, high incidence of acid tropical soils and land contamination due to mining and oil exploitation (Ibisch and Merida, 2003).

Within this context, the appropriate development of biotechnology as a complementary tool to genetic improvement of crops and crop production, can constitute a valuable tool for the sustainable development of the country, since it has the potential to help improve productivity, food security and the conservation of genetic resources. In spite of this, plant biotechnology applications must respond to increasing demands in terms of: food security, socioeconomic development, promotion of conservation, diversification and sustainable use of plant genetic resources as basic inputs for future agriculture. Advanced biotechnologies, such as cell and tissue culture, molecular genome analysis, plant genetic transformation, molecular plant disease diagnosis and germplasm cryoconservation, can be successfully used to cope with; genetic erosion, to reinforce ex situ collections and in situ conservation, to upgrade the supply of improved and healthy seeds and planting materials to farmers, and to integrate a new approach into the development programs for food production and feeding security in mountain lands.

\section{Objective}

The objective of this case study was to identify the biotechnological techniques that are being used in Bolivia within the agricultural sector, describe the institutional scenario in which these activities are conducted, analyze the legal and institutional framework for the management of biotechnology, situate the analysis within a regional and international context, and propose activities promoting the use and application of biotechnology.

\section{MATERIALS AND METHODS}

The Bolivia case study is part of an ongoing multiple study organized by FAO's regional office for Latin America and the Caribbean under REDBIO/FAO's network for Ecuador (Wendt and Izquierdo, 2003); Argentina (unpublished), Peru $^{1}$, Colombia ${ }^{2}$, Chile $^{3}$, Uruguay and Venezuela (planned for 2006).

The Bolivia study is based on information obtained through a bibliographical search and 41 interviews conducted during 2003 with experts from 30 Bolivian institutions involving management, regulation, research, innovation, 
application and education of agricultural biotechnology in the country.

Institutions interviewed:

1. Ministry of Farmer and Agricultural Affairs -

Technological Development Board.

2. Ministry of Sustainable Development - General

Biodiversity Board.

3. Ministry of Education - Educational Reform.

4. National Seed Program.

5. Santa Cruz Regional Seeds.

6. National Agricultural Sanitary and Food Safety Service.

7. Pairumani's Phytogenetic Research Center,

Cochabamba.

8. PROINPA Foundation, Cochabamba.

9. Forestry Seed Center Laboratory, BASFOR, UMSS, Cochabamba.

10. Potato Seed Production Unit, Cochabamba.

11. Biotechnology Laboratory, Faculty of Agricultural and

Livestock Science, UMSS, Cochabamba.

12. Agroindustrial Technology Center, Sciences and

Technology Faculty, UMSS, Cochabamba.

13. Vegetal Biotechnology Laboratory, Military

Engineering School, La Paz.

14. Molecular Biology and Biotechnology Institute,

UMSA, La Paz.

15. Bioplant Laboratory, El Vallecito Research Center, UAGRM, Santa Cruz.

16. GermoFAN Laboratory, Friends of Nature Foundation, Santa Cruz.

17. Tissue Culture and Phytopathology Laboratory,

UAJMS, Tarija.

18. Tissue Culture Laboratory, UMSFX, Sucre.

19. Micro-phyton Laboratory, Cochabamba.

20. Vitroplanta Laboratory, La Paz.

21. Bolivian Institute of Science and Nuclear Technology, La Paz.

22. Vegetal Biotechnology Laboratory, UTO, Oruro.

23. Bioinnovation Laboratory, La Paz.

24. Proveglass Laboratory, Oruro.

25. Wheat Program.

26. Alternative Development, DAI CONCADE.

27. Oilseed Producers National Association.

28. Research Center on Tropical Agriculture, Santa Cruz.

29. FOBOMADE.

30. Bolivia Holstein Association.

\section{RESULTS}

\section{Applied biotechnological techniques in Bolivia}

The applied biotechnological techniques that are being developed and adopted, at a national level, to support the development of the agricultural sector are: in vitro plant culture, molecular markers, assisted reproduction techniques in animals, and techniques supporting land and animal diagnosis. In addition, there are some new activities regarding the production of bioregulators and biopesticides as well, some laboratories are starting to apply the recombinant DNA technology mainly in microorganism research. In this practice over the past 10 years, the research and academic institutions have implemented molecular biology laboratories and others have widened and updated their facilities (REDBIO, Bolivia, 2002). Also, national experts obtaining postgraduate degrees abroad have returned to the country and are at the head of these biotechnology programs, thus permitting institutions to diversify activities. Nevertheless, a different situation is observed in private laboratories due to the economic crisis of the country; two laboratories, for example have, been forced to close down and others to reduce production.

The fields where biotechnological techniques are applied include the following.

Genetic resources. The PROINPA Foundation and the Pairumani Phytogenetic Research Center (CIFP) are using molecular markers to evaluate the diversity in the collections of both institutions. PROINPA is responsible for the Tuber, Andean Root Bank and High Andean Grain Bank. The Cereal and Legume Bank belongs to CIFP. PROINPA and CIFP are using in vitro techniques as part of the strategy for germplasm conservation. PROINPA also houses a security copy of the Bolivian collection of potatoes, other tubers and Andean roots. In addition, virus free indexing is being conducted on top priority varieties to be reintroduced on farmer lands and CIFP has an in vitro collection of Andean pasifloras.

In addition to these two institutions which form part of the National System of Genetic Resources for Food and Agriculture (SINARGEAA), the country has other laboratories which at present are carrying out in vitro conservation of genetic resources collections of sweet potato and cassava (El Vallecito Research Center, Gabriel Rene Moreno Autonomous University), orchids (Friends of Nature Foundation), native aromatics (Agro-industrial Technology Center, Mayor de San Simon University), high Andean grains (Biotechnology Laboratory of the Oruro Technical University), and other native plants (Molecular Biology and Biotechnological Institute -IBMB-, Mayor de San Andres University).

The IBMB is the largest molecular biology laboratory in the country and has the most experience. Various studies are being conducted on the genetic diversity of fish, plants and microorganisms.

Genetic improvement. Genetic improvement programs being conducted in the country are starting to implement biotechnological techniques to support the traditional ones. Thus, molecular markers, anther and protoplast culture, in vitro mutagenesis, among other techniques are being implemented in laboratories belonging to private research foundations and in universities. CIFP has implemented a Biotechnological Program with laboratories working on tissue cultivation and molecular biology to support genetic 
improvement programs of corn, beans, broad beans and peas. PROINPA is implementing a quinoa improvement program, using molecular biology.

Production and marketing. Likewise, there are examples of biotechnological techniques such as micro-propagation and embryo transplantation in bovines, which support productive processes that are economically and strategically important for the county. The Potato Seed Production Unit (SEPA) is the main institution producing certified seeds that have exported in vitro plants and elite seeds to neighbouring countries.

University laboratories support academic activities and mainly carry out research. Nevertheless, many of these laboratories are involved in commercial transactions to help cover their annual operational expenses.

- In the El Vallecito laboratory, work is being conducted with potentially commercial native fruit such as achachairu (Rheedia spp) and cherimoya (Annona cherimola), in addition to Stevia.

- The Military Engineering School laboratory is working on flower micro-propagation.

- The UMSS Plant Biotechnology Center is carrying out micro-propagation and mutagenesis of fruit trees.

- The Juan Misael Saracho University laboratory is working on viral free indexing of garlic and grape vines.

- At the UMSS Forestry Seed Center priority has been given to 40 native forestry species, some commercially valuable and others in danger of extinction, which are to be introduced in vitro for their multiplication and conservation.

There are no biotechnological enterprises making important investments in Bolivia. Nevertheless, there are private laboratories such as Proverglass and Vitroplanta, where flowers and maca are being produced.

With regard to the production of bio-controllers, PROBIOMA and PROINPA are developing commercial products to control disease and plagues.

Research in biotechnology. In Bolivia, research is mainly strategic at the intermediate level between basic and applied research, but applied research is also being conducted (Avila, 2002). Most of the research conducted by universities is not really related to the production sector needs or with the technology users. Research conducted by private foundations is based more on similar patterns and is supported by institutions.

\section{Limitations}

There are many limitations for an adequate development of biotechnology. Probably the most relevant are the lack of funds and the strong dependence on international cooperation for the operation of the laboratories and for the salaries of the scientists. This fact represents a challenge for researchers to strengthen coordination between the productive sector and research. Other limitations are the insufficient support favouring local production, high taxes on imports and acquisition of equipment and reagents and the lack of training on specific issues.

\section{Genetically modified organisms (GMOs)}

The following tests with genetically modified organisms (GMOs) have been conducted in Bolivia.

Frost resistant potatoes. (Initial request made in 1992). Tests were conducted in greenhouses and in the field over several consecutive years. Transgenic clones did not result as expected and trials were definitely suspended.

Cotton Bt Transformation event MON 531. (Initial request made in 1997). Two small-scale tests were conducted. A third compulsory test was suspended due to regulatory revisions and afterwards due to the fact that the Monsanto Enterprise had not requested the test. It has not been reactivated. Nevertheless, the main problem affecting the cultivation of cotton in the country is caused by lepidopteran insects. Consequently, cotton farmers are very interested in the reactivation of $\mathrm{Bt}$ cotton tests since they have to lower their production costs.

Soybean RR transformation event 40-3-2. (Initial request made in 1997). Three compulsory tests were conducted in the Santa Cruz region to analyze the environment impact. After these tests, a food safety assessment was conducted.

The soybean RR transformation event 40-3-2 has been approved (Multi Ministerial resolution $\mathrm{N}^{\circ} 01$, April 7, 2005) for commercial production and use in human food.

The introduction of this soybean is a challenge for the country, specially for the national biosafety system and the seed production system. The public expectation towards the safety of this product is higher than for any other produced food and it also worries the consumers.

The Regional Seed Office in Santa Cruz has periodically taken samples and carried out inspections in the production areas searching for transgenic soybean, which was supposedly, introduced in the country illegally. Samples were analyzed and no transgenic soybean was found until October, 2004 when approximately 400 hectares were found and their production was confiscated.

\section{Management of biotechnology}

The biotechnology management in Bolivia is under the Ministry of Farmer and Agricultural Affairs (MACA), through the Technological Development Board of the Vice- 
Ministry of Agriculture, Livestock and Fishing and the Ministry of Sustainable Development through the ViceMinistry of Natural Resources and Environment and the General Biodiversity Board. The latter is the competent local authority on issues regarding biosafety and access to genetic resources and has supported several activities to strengthen biotechnology and biosafety in the country.

Legally, Bolivia has a Regulation on Biosafety approved by Supreme Decree 24676 of June 1997, which is still in effect (MDSMA, 1997a). This Regulation stipulates that the Ministry of Sustainable Development is the Competent National Authority (CNA), through the Vice-Ministry of the Environment and Natural Resources. A National Committee on Biosafety (NCB) is created to act as the organization in charge of providing assistance and technical support to the CNA in activities related to biosafety. In addition, a National Strategy on Biotechnology Safety also exists, based on a diagnosis conducted in 1999 (MDSP, 1999). At present, the General Biodiversity Board is conducting a project financed by FAO to institutionally strengthen biosafety.

Decree 391 of the Andean Community member countries determines access to Bolivian genetic resource. A Supreme Decree regulates genetic resources in Bolivia (MDSMA, 1997b). Between 1997 and 2003, the Competent National Authority received new requests to access genetic resources. Up to now, only two access contracts have been granted. Bolivia still has not signed the International Treaty on Plant Genetic Resources for Food and Agriculture. Nevertheless, the respective Ministries are holding meetings and analyzing the issue with the different sectors.

As a country forming part of the Convention on Biological Diversity, it is not possible to obtain ownership rights in Bolivia on living materials through a system based on licenses. Nevertheless, there is a sui generis system to protect highly specific vegetal varieties. Through Law \#1968 of March 1999, Bolivia ratified its unification to the International Union for the Protection of Vegetal Acquisitions, under the Act of 1978. The Protection of Vegetal Acquisitions is legally based on Decision 345 of the Andean Community, a supra national regulation, which has the status of law in the country.

\section{Public perception}

In view of the requests to carry out transgenic plant tests and the strong discussion this has provoked, there is a perception in the country that does not distinguish between the recombinant DNA technology and the rest of the biotechnological techniques (Carrullo and Dellacha, 2003). This is due to the fact that the Bolivian society has not treated the issue of transgenic cultivation with the necessary balance. Scientists did not know how to clearly demonstrate potential benefits, there was no discussions generated in the media and these latter were more geared towards sensationalism. Some NGOs and ecological groups conducted alert campaigns towards the total rejection of transgenic use, exaggerating and distorting the true effects on people, domestic animals and the environment. In addition, information on regulations was not disseminated and authorities did not support the process with information on the issue.

The complexity of the subject and the trends that nowadays exist, require the perception and education campaigns for the public to be systematic and frequent. They must involve various sectors of society. Information must be reliable and scientifically based, transparent, and explain the risks and benefits of these technologies. Educational material elaborated by the REDBIO International Foundation and projects such as InfoREDBIO and PerciREDBIO can be instrumental to reach massive populations. In addition, initiatives like the "Biotechnology for policy managers course" organized by FAO/FODEPAL and REDBIO which is implemented yearly through the internet and the "Course on Biotechnological Communication" organized by REDBIO Bolivia in April 2004 are important in educating the public.

\section{CONCLUDING REMARKS AND FUTURE OPTIONS}

To improve the development of biotechnology in Bolivia, the present case study has identified the following three aspects on which work should be focused:

- Promotion of the use of appropriate biotechnology to solve important domestic problems. These must be adapted to our reality as a country, in harmony with the biodiversity and taking the production sector into account.

- An efficient regulatory biosafety system, intellectual property and access to genetic resources, which will lead to technological innovation and at the same time, safeguard our resources.

- Assurance that various actors in society are well informed so as to enrich discussions on the application of biotechnology and identify the best potential applications.

In order to develop biotechnology in the country, it is important that the technology be transparently promoted through the policies of the respective Ministries in charge of the biotechnology management "issue". This management, which has been deficient for a long time in Bolivia, has been improving since there are policies that promote research and the use of biotechnology. In addition, the country has the necessary tools to channel resources towards public and private institutions, starting with MACA, the SINARGEAA and the National Strategic Innovation Projects within the framework of the Bolivian System of Agricultural Technology (SIBTA) (Arteaga, 2004). All of this helps promote the use of biotechnology, 
benefiting the different production chains and the conservation of genetic resources.

In view of the country's specific needs and opportunities, biotechnology could, in the medium term, have a significant impact on improving the efficiency of production chains, particularly by providing assistance to input providers, improving seed production processes, production of biocontrollers, attainment of improved varieties, molecular characterization of germplasm, gene prospects, etc. Most of the institutions implementing agricultural biotechnology are focused on generating technology for small producers.

In addition, biotechnological techniques can be geared towards supporting diagnosis making the control of imported products more efficient and creating export reliability and credibility.

Finally, it is recommendable to analyze the special aspects that the present study has identified as important needs and targets for the development of biotechnology in the country. These are the following:

- The country's potential to develop biotechnology.

- Trends in the application of biotechnology in Bolivia.

- Points that have to be taken into account for the development of biotechnology.

- Policies supporting science and technology and the importing of equipment, material and reagents.

- Strategies and dissemination mechanisms including results obtained by biotechnological laboratories.

- Establishment of the REDBIO Foundation of Bolivia.

This study has indicated that it is fundamental to have clear regulations and appropriate conditions to attract private investment so that innovation and investment in biotechnology can prosper in the country. Nevertheless, it is also important to promote research and the products that are elaborated in public laboratories.

In the IV National Meeting on Biotechnology and Biosafety (November 2004), it was suggested to have a REDBIO meeting during the year 2005 to analyze these important aspects.

\section{REFERENCES}

ARTEAGA, R. SINARGEAA, Nuestra estrategia para conservar la riqueza genética boliviana. In: Congreso Internacional de Cultivos Andinos. $\left(11^{\mathrm{o}}, 3^{\text {th }}-6^{\text {th }}\right.$ February, 2004, Cochabamba, Bolivia). 2004. Abstracts in CD-ROM.
AVILA, G. Visión general de la investigación agrícola en Bolivia. In: Seminario sobre la investigación agricola en Bolivia. (12th-13thSeptember, 2002, Santa Cruz, Bolivia). 4 p.

CAMBIOTEC. La Biotecnología en América Latina: Panorama al año 2002. VERÁSTEGUI, J. ed. IDRC, Canadá, 2003. 237 p. ISBN 987-20494-3-2.

CARRULLO, J.C. and DELLACHA, J. La percepción pública de la ciencia: El caso de la biotecnología. UNU/BIOLAC, RNBio, Instituto de Estudios Sociales de Ciencia y Tecnología, Universidad Nacional de Quilmes, Argentina, 2003. 62 p. ISBN 987-20494-2-4.

IBISCH, P. and MERIDA, G. Biodiversidad: La riqueza de Bolivia. Estado de conocimiento y conservación. Editorial FAN, Santa Cruz, Bolivia, 2003. 638 p. ISBN 99905-6625-9.

INTERNATIONAL SERVICE FOR THE ADQUISITION OF AGRI-BIOTECH APPLICATIONS. Yearly Report 2004. Available from Internet: http://www.isaaa.org.

MINISTERIO DE DESARROLLO SOSTENIBLE Y MEDIO AMBIENTE, SECRETARIA NACIONAL DE RECURSOS NATURALES Y MEDIO AMBIENTE (MDSMA). Reglamento sobre Bioseguridad. La Paz, Bolivia, 1997a. 23 p.

MINISTERIO DE DESARROLLO SOSTENIBLE Y MEDIO AMBIENTE, SECRETARIA NACIONAL DE RECURSOS NATURALES Y MEDIO AMBIENTE. (MDSMA) Reglamento de la Decisión 391 Régimen Común de Acceso a los Recursos Genéticos. La Paz, Bolivia, 1997b. 28 p.

MINISTERIO DE DESARROLLO SOSTENIBLE Y PLANIFICACION (MDSP). Estrategia Nacional de Seguridad de la Biotecnología. Proyecto GEF/1200-98-71 VMARNDF/DGB - PNUMA/FMAN, La Paz, Bolivia, 1999. $30 \mathrm{p}$.

REDBIO BOLIVIA. Memorias de la III Reunión Nacional de Biotecnologia. $\left(24^{\text {th }}-26^{\text {th }}\right.$ April, 2002, Oruro Bolivia). AVILA, T.; VILLARROEL, C.L. and BLANCO, R., eds. 2002. Abstracts in CD-ROM.

WENDT, J. and IZQUIERDO, J. Management of appropriate agricultural biotechnology for small producers: case study - Ecuador. Electronic Journal of Biotechnology [online]. 15 April 2003, vol. 6, no. 1. Available from Internet:

http://www.ejbiotechnology.info/content/vol6/issue1/issues /02/index.html.

${ }^{1}$ Manejo y gestión de la biotecnología agrícola apropiada para pequeños productores: Estudio de caso: ARGENTINA http://www.redbio.org/documentos/manejo_y_gestion.doc 
Management of the appropriate agricultural biotechnology for small producers: Bolivia case study

${ }^{2}$ Manejo de la Biotecnología Apropiada para pequeños agricultores : Estudio de caso:PERU http://www.redbio.org/e_casos/Adjunto_Peru.pdf

${ }^{3}$ Manejo y gestión de la biotecnología agrícola apropiada para pequeños productores: Esrudio de caso: COLOMBIA http://www.redbio.org/e_casos/colombia.doc 